\title{
EVALUASI KOORDINASI PROTEKSI RELAY ARUS LEBIH DAN RELAY GANGGUAN TANAH PADA PENYULANG KEDONGANAN DAN GARDENIA GI NUSA DUA MENGGUNAKAN ETAP 12.6.0
}

\author{
Andri Laksono*), Hermawan, Agung Nugroho \\ Departemen Teknik Elektro, Universitas Diponegoro \\ Jl. Prof. Sudharto, SH, Kampus UNDIP Tembalang, Semarang 50275, Indonesia \\ ${ }^{*}$ Email: andrilaksono@gmail.com
}

\begin{abstract}
Abstrak
Sistem distribusi tenaga listrik adalah bagian dari sistem tenaga listrik yang berfungsi menyalurkan listrik dari pembangkit tenaga listrik hingga ke konsumen. Evaluasi proteksi meliputi koordinasi antar peralatan proteksi dalam jaringan distribusi yang harus memenuhi standart yang ada. Penelitian ini membahas tentang evaluasi koordinasi proteksi Relay Arus Lebih dan Relay Gangguan Tanah penyulang Kedonganan dan Gardenia GI Nusa Dua menggunakan aplikasi ETAP 12.6.0. Nilai setting relay arus lebih dan relay gangguan tanah ditentukan berdasarkan pada standart IEC 60255, relay yang terpasang pada GI Nusa Dua memiliki kurva karakteristik Standart Inverse. Hasil simulasi menunjukkan pada penyulang Kedonganan dan Gardenia dalam kondisi eksisting belum sesuai dengan standart. Pada gangguan 3 fasa, interval waktu kerja antar relay kondisi eksisting adalah sebesar 0,510 detik untuk kedua feeder, sedangkan pada kondisi resetting memiliki interval waktu 0,331 detik untuk feeder Kedonganan. Interval yang diizinkan berdasarkan standart IEC 60255 adalah 0,3-0,5 detik. Pada kondisi resetting, untuk gangguan 2 fasa diujung saluran, relay incoming memiliki waktu kerja sebesar 1,099 detik untuk feeder Kedonganan.
\end{abstract}

Kata Kunci: distribusi tenaga listrik, evaluasi koordinasi proteksi, gangguan hubung singkat, relay gangguan tanah, relay arus lebih, ETAP 12.6.0

\begin{abstract}
Electrical distribution as a part of electrical power system has main function to feed electricity from power plant to consumers. The evaluation of protection includes coordination between the protection equipment in the distribution network with existing standart. This research present the coordination of protection especially Over Current Relay and Ground Fault Relay in Kedonganan and Gardenia feeder on Nusa Dua Substation using ETAP 12.6.0. The value of current relay setting is referring to IEC 60255, because the relay is mounted on Nusa Dua Substation with characteristic curve of Standart Inverse. The calculation based on the calculation will compared and analyzed by the existing setting. The simulation results show that the relay on Kedonganan and Gardenia feeder had an exisiting setting which not comfort with the standart. In a 3 phase fault, the feeders have time interval between in $0,510 \mathrm{sec}$ while the resetting condition has a time interval of 0,331 seconds for Kedonganan. Those time intervals did not comfort the standart of IEC 60255 which was $0,3-0,5$ second. In resetting condition, an incoming relay only required of 1,099 seconds for Kedonganan. The resetting calculation has a faster working time so that the maximum resistance of the conductor can be achieved.
\end{abstract}

Keywords: electrical distribution system, evaluation and coordination protection system, over current relay, ground fault relay, ETAP 12.6.0

\section{Pendahuluan}

Sistem distribusi merupakan bagian dari sistem tenaga listrik yang berfungsi menyalurkan sumber daya listrik hingga ke konsumen[10]. Bertambahnya jumlah beban sejalan dengan pertumbuhan jumlah penduduk, dapat berakibat terjadinya persentasi kenaikan gangguan. Hal tersebut dapat mempengaruhi kerja relay proteksi yang terpasang pada jaringan distribusi. Sehingga diperlukan sebuah sistem proteksi yang handal untuk mengamankan peralatan dan jaringan distribusi ketika mengalami gangguan. Bentuk gangguan hubung singkat yang terjadi pada sistem distribusi tenaga listrik umumnya berupa gangguan tiga fasa, antar fasa maupun gangguan fasa ke tanah[6]. Faktor-faktor yang mempengaruhi terjadinya gangguan berupa faktor internal maupun faktor eksternal [2]. Koordinasi antara peralatan proteksi menentukan keandalan suatu proteksi, salah satu koordinasi yang harus 
dijaga adalah koordinasi antara relay arus lebih (OCR) dan relay gangguan tanah (GFR)[9]. Sistem proteksi yang sudah diterapkan pada jaringan distribusi di Gardu Induk Nusa Dua belum dilakukan evaluasi kinerja relay arus lebih dan relay gangguan tanah sebelumnya. Berita acara PLN Distribusi Bali, Area Bali Selatan pada bulan Agustus tahun 2017, menyebutkan bahwa telah terjadi kegagalan relay outgoing dan relay incoming untuk memutus gangguan yang terjadi pada penyulang Kedonganan menyebabkan terjadinya tripping peralatan proteksi di sisi tegangan $150 \mathrm{kV}$ trafo sehingga trafo 360 MVA Gardu Induk Nusa Dua mengalami pemadaman.

Berdasarkan hal tersebut akan dilakukan evaluasi kinerja relay arus lebih (OCR) dan relay hubung tanah (GFR) pada relay incoming dan relay outgoing penyulang Kedonganan dan Gardenia di Trafo 3 berkapasitas 60 MVA Gardu Induk Nusa Dua. Evaluasi didasarkan pada analisis gangguan hubung singkat pada penyulang Kedonganan dan Gardenia di GI Nusa Dua.

Penentuan dan perhitungan setting relay arus lebih pada Penelitian ini mengacu pada IEC 60255[4]. Hal ini dikarenakan sebagian besar relay yang digunakan pada Gardu Induk Nusa Dua menerapkan kurva karakteristik IEC Standart Inverse [4] sehingga penentuan setting relay berdasarkan standart IEC 60255.

Dengan adanya evaluasi dan resetting koordinasi proteksi ini menghasilkan koordinasi peralatan proteksi yang lebih baik.

\section{Metode}

\subsection{Langkah Penelitian}

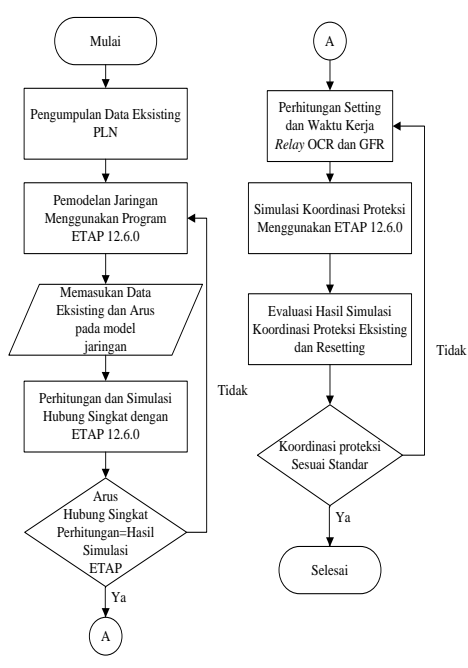

Gambar 1.Langkah Penelitian Koordinasi Relay Arus Lebih dan Relay Gangguan Tanah GI Nusa Dua
Pada penelitian ini menjelaskan tentang proses evaluasi setting relay yaitu relay arus lebih dan relay gangguan tanah di sisi incoming dan outgoing pada GI Nusa Dua. Perangkat lunak yang akan di gunakan adalah Electrical Transient Analysis Program (ETAP) 12.6.0. Secara umum langkah penelitian yang dilakukan sebagaimana terlihat pada Gambar 1.

\subsection{Data Sistem}

Diagram satu garis pada kondisi existing dari sistem kelistrikan Gardu Induk Nusa Dua Trafo III pada Gambar 2 .

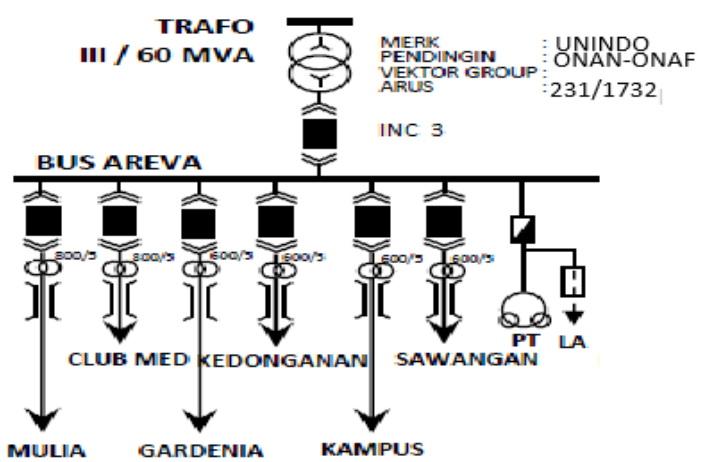

Gambar 2. Diagram Satu Garis Jaringan Distribusi 20 kV GI Nusa Dua

Adapun data yang digunakan adalah seperti pada Tabel berikut:

Tabel 1. Data Trafo Tenaga [3]

\begin{tabular}{cc}
\hline \multicolumn{3}{c}{ Data Trafo Tenaga } \\
\hline Merk & UNINDO \\
Daya & $60 \mathrm{MVA}$ \\
Tegangan & $150 / 20 \mathrm{Kv}$ \\
Impedansi $(\mathrm{Z} \%)$ & $12.240 \%$ \\
Rasio CT $(20 \mathrm{kV})$ & $2000 / 5$ \\
Vektor Grup & YNyn0+d \\
Jumlah Tap & 18 \\
\hline
\end{tabular}

Tabel 2. Data Power Grid [1]

\begin{tabular}{cc}
\hline Kondisi & MVAsc 3 fasa \\
\hline Eksisting & $3250,193 \mathrm{MVA}$ \\
\hline
\end{tabular}

Tabel 3. Data Relay OCR dan GFR Incoming [1]

\begin{tabular}{cc}
\hline \multicolumn{2}{c}{ Data Relay OCR \& GFR Incoming } \\
\hline Merk & AREVA \\
Type & MICOM P127 \\
Karakteristik & Standart Invers \\
I setting OCR & $2080 \mathrm{~A}$ \\
I setting GFR & $700 \mathrm{~A}$ \\
Rasio CT & $2000 / 5$ \\
TMS OCR & 0,19 \\
TMS GFR & 0,45 \\
\hline
\end{tabular}


Tabel 4. Data Relay OCR dan GFR Outgoing [8]

\begin{tabular}{|c|c|c|c|c|c|c|c|}
\hline \multirow[b]{2}{*}{ Penyulang } & \multirow[b]{2}{*}{ Merk } & \multirow[b]{2}{*}{$\begin{array}{l}\text { Rasi } \\
\text { O CT }\end{array}$} & \multirow{2}{*}{$\begin{array}{l}\text { Kurva } \\
\text { Karakt } \\
\text { eristik }\end{array}$} & \multicolumn{2}{|c|}{ OCR } & \multicolumn{2}{|c|}{ GFR } \\
\hline & & & & $\begin{array}{l}\text { Iset } \\
\text { (A) }\end{array}$ & TMS & $\begin{array}{l}\text { Iset } \\
\text { (A) }\end{array}$ & TMS \\
\hline $\begin{array}{c}\text { Kedonga } \\
\text { nan }\end{array}$ & $\begin{array}{c}\text { MICOM } \\
\text { P123 }\end{array}$ & $\begin{array}{c}600 / \\
5\end{array}$ & IEC SI & 300 & 0,175 & 100 & 0,25 \\
\hline Gardenia & $\begin{array}{l}\text { MICOM } \\
\text { P123 }\end{array}$ & $\begin{array}{c}600 / \\
5\end{array}$ & $\mathrm{CSI}$ & 300 & ,175 & 100 & 0,25 \\
\hline
\end{tabular}

Tabel 5. Data Penyulang Trafo III GI Nusa Dua [8]

\begin{tabular}{ccccc}
\hline Penyulang & $\begin{array}{c}\text { Panjang } \\
(\mathbf{k m})\end{array}$ & $\begin{array}{c}\text { Arus } \\
(\mathbf{A})\end{array}$ & $\begin{array}{c}\text { Beban } \\
\text { (MVA) }\end{array}$ & $\begin{array}{c}\text { Tegangan } \\
\text { Pangkal } \\
\text { Terukur } \\
\text { (KV) }\end{array}$ \\
\hline Kedonganan & 7,319 & 172 & 6,06 & 19,81 \\
Gardenia & 5,8 & 104 & 3,65 & 19,81 \\
\hline
\end{tabular}

Tabel 6. Data Teknis Penghantar [6]

\begin{tabular}{|c|c|c|c|c|c|c|}
\hline \multirow{2}{*}{$\begin{array}{c}\text { Jenis } \\
\text { Penghant } \\
\text { ar }\end{array}$} & \multirow{2}{*}{$\begin{array}{c}\text { Luas } \\
\text { Penampan } \\
\mathrm{g}\left(\mathrm{mm}^{2}\right)\end{array}$} & \multirow{2}{*}{$\begin{array}{c}\text { KHA } \\
\text { (Ampere } \\
\text { ) }\end{array}$} & \multicolumn{2}{|c|}{$\begin{array}{c}\mathrm{Z1}=\mathrm{Z2} \\
\text { (ohm/Km) }\end{array}$} & \multicolumn{2}{|c|}{$\mathrm{ZO}$ (ohm/Km) } \\
\hline & & & $\mathbf{R}$ & $\mathrm{jX}$ & $\mathbf{R}$ & $\mathrm{jX}$ \\
\hline AAAC & $240 \mathrm{~mm}^{2}$ & 585 & $\begin{array}{c}0,134 \\
4\end{array}$ & $\begin{array}{c}0,315 \\
8\end{array}$ & $\begin{array}{c}0,282 \\
4\end{array}$ & $\begin{array}{c}1,603 \\
3\end{array}$ \\
\hline
\end{tabular}

\subsection{Pemodelan}

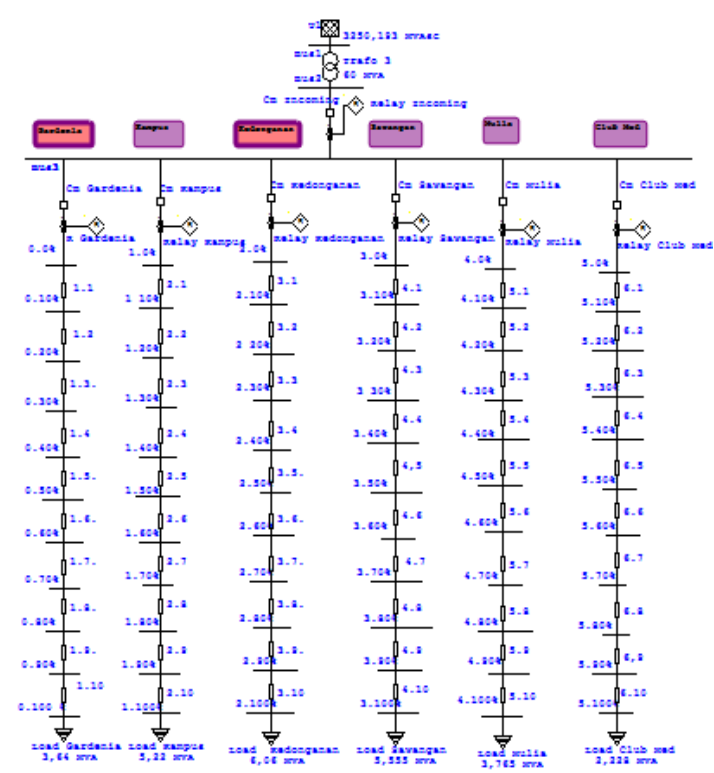

Gambar 3. Pemodelan Diagram Satu Garis Jaringan Existing

Berdasarkan pada data existing jaringan yang diperoleh maka dapat dibuat pemodelan diagram satu garis menggunakan program ETAP 12.6.0 seperti pada Gambar 3.

\section{Hasil dan Analisa}

Dalam bab ini, akan membahas tentang arus hubung singkat dan setting relay arus lebih dan relay gangguan tanah pada trafo III 60 MVA Gardu Induk Nusa Dua, untuk menentukan koordinasi relay arus lebih dan relay gangguan tanah menggunakan ETAP 12.6.0 dan perhitungan manual.

\subsection{Simulasi Aliran Daya}

Simulasi aliran daya dilakukan menggunakan mепи Load Flow Analysis pada program ETAP 12.6.0. Data yang digunakan adalah data pada Tabel 1 hingga Tabel 6 dan pemodelan jaringan seperti Gambar 3.

Tabel 7. Data Tegangan Pangkal dan Arus Tiap Penyulang Hasil Simulasi

\begin{tabular}{ccccc}
\hline Penyulang & $\begin{array}{c}\text { Panjang } \\
\text { Saluran } \\
(\mathbf{k m})\end{array}$ & $\begin{array}{c}\text { Arus } \\
\text { (Ampere) }\end{array}$ & $\begin{array}{c}\text { Tegangan } \\
\text { Pangkal } \\
\text { Existing } \\
\mathbf{( k V )}\end{array}$ & $\begin{array}{c}\text { Tegangan } \\
\text { Pangkal } \\
\text { Hasil } \\
\text { Simulasi } \\
\mathbf{( k V )}\end{array}$ \\
\hline Kedonganan & 7,319 & 172 & 19,81 & 19,99 \\
Gardenia & 5,8 & 104 & 19,81 & 19,99 \\
\hline
\end{tabular}

Berdasarkan Tabel 7 menunjukan nilai tegangan pangkal dan arus yang mengalir tiap penyulang. Tegangan pada pangkal tiap penyulang yang didapat dari hasil simulasi adalah 19,99 kV dimana memiliki nilai yang hampir sama dengan besar tegangan terukur pada pangkal penyulang hasil pengambilan data existing, sehingga pemodelan dan konfigurasi jaringan sudah sesuai. Besarnya nilai arus total yang mengalir dari Trafo III 60 MVA didapat dengan menjumlahkan besar keseluruhan arus masingmasing saluran, sehingga didapat arus sebesar 276 Ampere.

\subsection{Menentukan Arus Hubung Singkat}

Untuk menentukan arus hubung singkat dilakukan dengan 2 metode yaitu dengan menggunakan simulasi pada program ETAP 12.6.0 dan perhitungan manual. Setelah dilakukan simulasi arus hubung singkat dan perhitungan manual hubung singkat maka diperoleh besar arus gangguan hubung singkat pada titik 0\% hingga 100\% dari panjang penyulang outgoing Trafo III GI Nusa Dua . Hasil besar arus hubung singkat pada penyulang Kedonganan yang diperoleh dari simulasi dapat dilihat pada Tabel 8. 
Tabel 8. Hasil Perhitungan dan Simulasi Arus Hubung Singkat Penyulang Kedonganan

\begin{tabular}{|c|c|c|c|c|c|c|c|c|}
\hline \multirow[b]{3}{*}{$\begin{array}{c}\text { Jarak } \\
(\%)\end{array}$} & \multicolumn{6}{|c|}{ Arus Hubung Singkat (A) } & \multirow{2}{*}{\multicolumn{2}{|c|}{1 fasa-g }} \\
\hline & \multicolumn{2}{|c|}{3 fasa } & \multicolumn{2}{|c|}{2 fasa } & \multicolumn{2}{|c|}{2 fasa-g } & & \\
\hline & $\begin{array}{l}\text { Perhi- } \\
\text { tungan }\end{array}$ & $\begin{array}{c}\text { Simula } \\
\text { si }\end{array}$ & $\begin{array}{c}\text { Perhi- } \\
\text { tunga } \\
\text { n }\end{array}$ & $\begin{array}{c}\text { Simula } \\
\text { si }\end{array}$ & $\begin{array}{c}\text { Perhi- } \\
\text { tunga } \\
\mathrm{n}\end{array}$ & $\begin{array}{c}\text { Simula } \\
\text { si }\end{array}$ & $\begin{array}{c}\text { Perhi- } \\
\text { tunga } \\
\text { n }\end{array}$ & $\begin{array}{c}\text { Simula } \\
\text { si }\end{array}$ \\
\hline $0 \%$ & 12,348 & 12,322 & 10,648 & 10,671 & 12,295 & 12,322 & 12,295 & 12,322 \\
\hline $10 \%$ & 9,885 & 9,849 & 8,515 & 8,529 & 6,391 & 6,269 & 7,746 & 7,757 \\
\hline $20 \%$ & 8,159 & 8,171 & 7,066 & 7,076 & 4,308 & 4,185 & 5,639 & 5,645 \\
\hline $30 \%$ & 6,959 & 6,968 & 6,027 & 6,035 & 3,248 & 3,192 & 4,429 & 4,433 \\
\hline $40 \%$ & 6,062 & 6,068 & 5,249 & 5,255 & 2,606 & 2,497 & 3,644 & 3,64 \\
\hline $50 \%$ & 5,365 & 5,371 & 4,647 & 4,651 & 2,176 & 2,088 & 3,095 & 3,094 \\
\hline $60 \%$ & 4,811 & 4,815 & 4,167 & 4,170 & 1,868 & 1,735 & 2,690 & 2,69 \\
\hline $70 \%$ & 4,359 & 4,363 & 3,775 & 3,779 & 1,636 & 1,621 & 2,378 & 2,379 \\
\hline $80 \%$ & 3,985 & 3,988 & 3,451 & 3,454 & 1,455 & 1,439 & 2,131 & 2,132 \\
\hline $90 \%$ & 3,669 & 3,672 & 3,177 & 3,180 & 1,310 & 1,297 & 1,930 & 1,93 \\
\hline $100 \%$ & 3,399 & 3,402 & 2,944 & 2,946 & 1,192 & 1,179 & 1,764 & 1,76 \\
\hline$\varepsilon_{\mathrm{r}}$ & \multicolumn{2}{|c|}{$0,108 \%$} & \multicolumn{2}{|c|}{$0,105 \%$} & \multicolumn{2}{|c|}{$2,39 \%$} & \multicolumn{2}{|c|}{$0,086 \%$} \\
\hline
\end{tabular}

Berdasarkan Tabel 8 dapat dilihat perbandingan antara perhitungan arus hubung singkat secara manual dan menggunakan software ETAP. Saat gangguan 3 fasa terjadi pada titik $0 \%$ hingga $100 \%$ nilai gangguan pada ETAP dan perhitungan manual memiliki nilai yang hampir sama, pada gangguan 3 fasa memiliki selisih rata - rata sebesar $0,108 \%$. Terlihat pula arus hubung singkat pada saat gangguan 2 fasa memiliki seslisih rata - rata $0,105 \%, 2$ fasa ke tanah memiliki selisih rata - rata 2,39\%, dan 1 fasa ke tanah memiliki selisih $0,086 \%$. Berdasarkan hasil analisa arus gangguan hubung singkat hasil simulasi dan perhitungan manual didapatkan semakin panjang saluran maka arus gangguan hubung singkat semakin kecil [2].

\subsection{Resetting Relay OCR dan Relay GFR}

Penentuan setting waktu kerja (Top) berdasarkan grading time antar peralatan proteksi sesuai IEC 60255 sebesar 0,3-0,5 detik [4]. Berikut merupakan rumus perhitungan setting relay OCR dan GFR pada penyulang Kedonganan Trafo III 60 MVA Gardu Induk Nusa Dua sesuai dengan standart IEC 60255 dengan karakteristik standart invers.

\section{- Rumus TMS OCR}

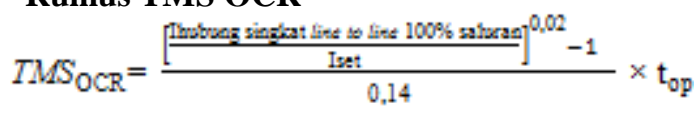

\section{- $\quad$ Rumus TMS GFR}

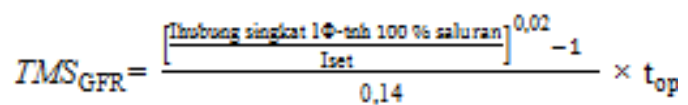

\section{- Iset OCR}

Iset $>\frac{\text { Kuat Hantar Arus Penyulang }}{0,95}$

- Iset GFR

Iset $=0,3 \times$ Iset OCR Penyulang
Sesuai dengan standart IEC 60255, untuk perhitungan relay incoming, digunakan cara yang sama seperti perhitungan OCR dan GFR outgoing. Perbedaan terletak pada besar arus gangguan yang dipilih, yaitu merupakan gangguan pada busbar utama dan waktu kerja yang digunakan pada persamaan adalah hasil dari grading time dengan waktu operasi relay outgoing pada gangguan di busbar utama setelah di grading sebesar 0,3 - 0,5 detik [4].

Tabel 9. Perbandingan Setting Relay OCR dan GFR Incoming Kondisi Existing Dan Resetting

\begin{tabular}{|c|c|c|c|c|}
\hline \multirow[t]{2}{*}{ Setting } & \multicolumn{2}{|c|}{$\begin{array}{l}\text { Setting Relay Incoming } \\
\text { Existing }\end{array}$} & \multicolumn{2}{|c|}{$\begin{array}{l}\text { Setting Relay incoming } \\
\text { Resetting }\end{array}$} \\
\hline & OCR & GFR & OCR & GFR \\
\hline TMS & 0,22 & 0,45 & 0,195 & 0,3089 \\
\hline$I_{\text {set }}(A)$ & 2080 & 700 & 800 & 240 \\
\hline
\end{tabular}

Tabel 10. Perbandingan Setting Relay OCR dan GFR Outgoing Kondisi Existing Dan Resetting

\begin{tabular}{cccccc}
\hline \multirow{2}{*}{ Penyulang } & \multirow{4}{*}{ setting } & \multicolumn{4}{c}{ Setting Relay Outgoing } \\
& & OCR & GFR & OCR & GFR \\
\hline \multirow{2}{*}{ Kedonganan } & TMS & 0,175 & 0,25 & 0,0678 & 0,098 \\
& Iset (A) & 300 & 100 & 620 & 186 \\
\multirow{2}{*}{ Gardenia } & TMS & 0,175 & 0,25 & 0,0738 & 0,1072 \\
& Iset (A) & 300 & 100 & 620 & 186 \\
\hline
\end{tabular}

Setting relay yang dipasangkan pada penyulang outgoing harus lebih besar dari KHA (Kuat Hantar Arus) penghantar dibagi dengan 0,95 sebagai toleransi kesalahan relay dalam mendeteksi arus gangguan [4]. Sehingga besar setting OCR dipilih sebesar 585 Ampere. Persyaratan yang harus dipenuhi yaitu untuk penyetelan waktu grading time relay di penyulang tidak boleh kurang dari 0,3 detik dan tidak boleh lebih dari 0,5 detik [4]. Keputusan ini diambil agar memberi kesempatan relay outgoing bekerja terlebih dahulu sedangkan relay incoming sebagai backup protection jika relay outgoing gagal bekerja.

Perbedaan nilai TMS pada setting relay kondisi existing dan perhitungan dikarenakan pada penentuan nilai Iset dan waktu kerja (Top) yang berbeda. PLN Distribusi Bali memiliki karakteristik dan pertimbangan tersendiri untuk masalah setting proteksi sehingga nilai antara kondisi eksisting dengan kondisi resetting hasil perhitungan memiliki perbedaan.

\subsection{Evaluasi Koordinasi Setting Relay OCR dan GFR}

Pada Gambar 4 dan gambar 5 merupakan koordinasi relay dari penyulang Kedonganan menggunakan perintah "star protective device coordination" pada simulasi ETAP 12.6.0. Berikut adalah gambar kurva arus terhadap waktu yang ditunjukan oleh Gambar 4 menunjukan kurva arus terhadap waktu koordinasi proteksi pada penyulang Kedonganan hasil resetting berdasarkan IEC 60255. 
Gambar 5 menunjukan kurva arus terhadap waktu koordinasi proteksi setting eksisting. Berikut adalah gambar kurva arus terhadap waktu yang ditunjukan oleh Gambar 4 menunjukan kurva arus terhadap waktu koordinasi proteksi hasil resetting berdasarkan standart IEC 60255 dan Gambar 5 menunjukan kurva arus terhadap waktu koordinasi proteksi setting existing pada penyulang Kedonganan. Tabel 11 dan Tabel 12 menunjukan perbandingan waktu kerja peralatan proteksi penyulang Kedonganan setting existing dan resetting. Pada gambar 4(a) dapat dilihat bahwa ketika terjadi gangguan 2 fasa pada ujung saluran yang akan mendeteksi adanya gangguan terlebih dahulu yaitu relay outgoing yang disetting selama 0,367 detik, dilanjutkan oleh relay incoming yang disetting sebesar 1,099 detik sebagai backup proteksi. Pada gambar 5(b) dapat dilihat bahwa ketika terjadi gangguan fasa tanah di ujung saluran yang akan mendeteksi terlebih dahulu adalah relay outgoing yang disetting 0,658 detik dilanjutkan dengan relay incoming sebesar 3,414 detik.

\section{Koordinasi Setting Relay Penyulang Kedonganan}

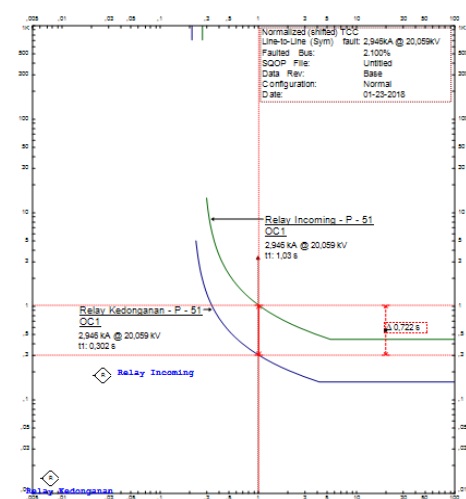

(a)

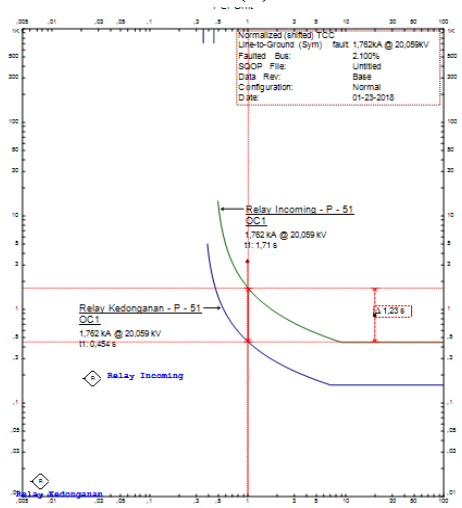

(b)

Gambar 4. Tampilan Kurva Arus-Waktu Koordinasi Relay Hasil Resetting pada ETAP 12.6.0 Kedonganan (a) Kurva TCC OCR, (b)Kurva TCC GFR

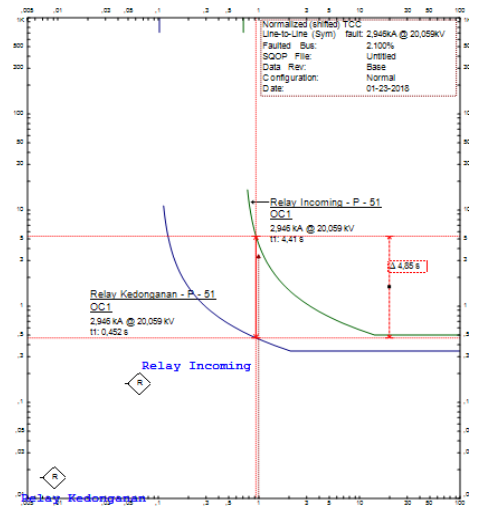

(a)

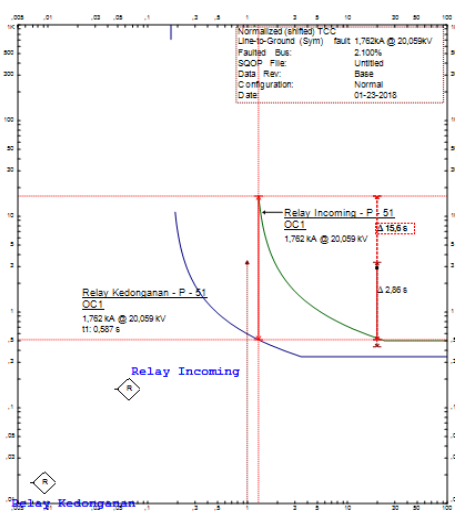

(b)

Gambar 5. Tampilan Kurva Arus-Waktu Koordinasi Relay setting existing pada ETAP 12.6.0 Kedonganan (a) Kurva TCC OCR, (b) Kurva TCC GFR

Gambar 4 menunjukan kurva koordinasi antara relay incoming dan relay outgoing dan urutan kerja apabila terjadi gangguan hubung singkat pada hasil resetting berdasarkan standart IEC 60255 dan Gambar 5 menunjukan kurva koordinasi antara relay incoming dan relay outgoing pada setting existing. Kedua gambar kurva hasil resetting dan existing menunjukan bahwa tidak ada berpotongan baik antara relay incoming dan relay outgoing. Hal ini menujukkan urutan kerja relay telah sesuai dan tidak ada overlapping antar relay.

Tabel 11. Perbandingan Waktu Kerja Relay Incoming Setting Existing Dan Perhitungan (Resetting)

\begin{tabular}{|c|c|c|c|c|c|c|c|c|}
\hline \multirow{2}{*}{$\begin{array}{l}\text { Jarak } \\
(\mathrm{km})\end{array}$} & \multicolumn{4}{|c|}{$\begin{array}{l}\text { Relay Incoming } \\
\text { (Existing) }\end{array}$} & \multicolumn{4}{|c|}{$\begin{array}{l}\text { Relay Incoming } \\
\text { (Resetting) }\end{array}$} \\
\hline & 3 fasa & 2 fasa & $\begin{array}{c}1 \\
\text { fasa-g }\end{array}$ & $\begin{array}{c}2 \\
\text { fasa-g }\end{array}$ & 3 fasa & 2 fasa & $\begin{array}{c}1 \\
\text { fasa-g }\end{array}$ & $\begin{array}{c}2 \\
\text { fasa-g }\end{array}$ \\
\hline 0 & 0,915 & 0,991 & 1,135 & 1,135 & 0,551 & 0,578 & 0,766 & 0,766 \\
\hline 0,7319 & 1,040 & 1,141 & 1,339 & 1,452 & 0,595 & 0,628 & 0,766 & 0,766 \\
\hline 1,4638 & 1,175 & 1,307 & 1,592 & 1,758 & 0,639 & 0,678 & 0,766 & 0,792 \\
\hline 2,1957 & 1,323 & 1,495 & 1,732 & 2,074 & 0,682 & 0,727 & 0,785 & 0,874 \\
\hline 2,9276 & 1,488 & 1,711 & 1,934 & 2,419 & 0,725 & 0,777 & 0,839 & 0,952 \\
\hline 3,6595 & 1,673 & 1,963 & 2,141 & 2,796 & 0,768 & 0,827 & 0,890 & 1,026 \\
\hline 4,3914 & 1,884 & 2,264 & 2,359 & 3,222 & 0,812 & 0,878 & 0,939 & 1,099 \\
\hline 5,1233 & 2,128 & 2,629 & 2,591 & 3,714 & 0,856 & 0,931 & 0,987 & 1,171 \\
\hline 5,8552 & 2,416 & 3,087 & 2,840 & 4,296 & 0,901 & 0,985 & 1,034 & 1,243 \\
\hline 6,5871 & 2,760 & 3,678 & 3,114 & 5,012 & 0,947 & 1,041 & 1,081 & 1,320 \\
\hline 7,319 & 3,180 & 3,374 & 3,414 & 5,903 & 0,994 & 1,099 & 1,128 & 1,397 \\
\hline
\end{tabular}


Berdasarkan Tabel 11 menunjukan waktu operasi relay incoming setting existing dan resetting. Relay hasil resetting pada incoming memberikan waktu operasi yang relatif lebih baik dan lebih cepat dibandingkan relay pada kondisi existing. Relay incoming pada kondisi existing tetap bekerja pada jarak 0\% $-100 \%$ dengan waktu kerja yang sedikit lebih lama dibandingkan relay pada kondisi resetting. Relay pada kondisi resetting diatur agar tetap bekerja sebagai back-up relay outgoing ketika gangguan berada diujung saluran.

Tabel 12. Perbandingan Waktu Kerja Relay Outgoing Setting Existing Dan Perhitungan (Resetting)

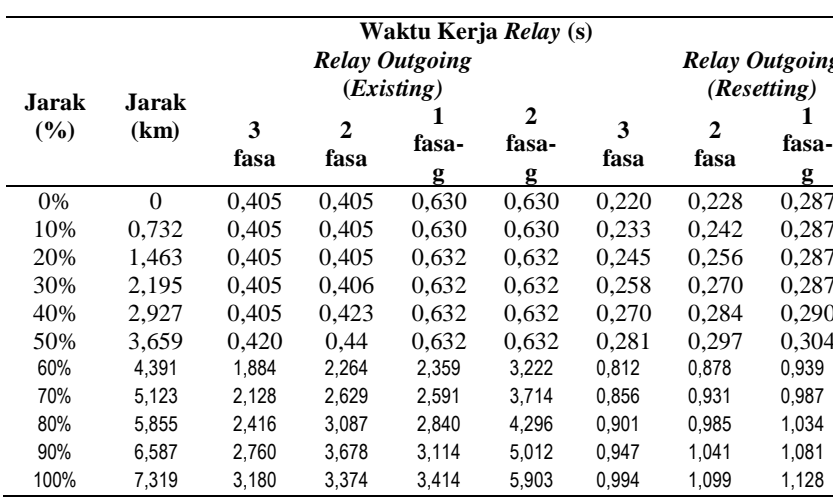

Berdasarkan Tabel 12 menunjukan waktu operasi relay outgoing secara keseluruhan menunjukan perbedaan nilai antara setting proteksi existing dan resetting. Hasil resetting relay outgoing memberikan waktu operasi yang lebih cepat dibandingkan setting proteksi pada kondisi existing. Setting relay proteksi hasil resetting mampu memberikan hasil koordinasi antara relay incoming dan relay outgoing lebih cepat dan lebih baik dibandingkan setting proteksi existing. Relay incoming dan outgoing setting existing pada gangguan 3 fasa, 2 fasa, 1 fasa-tanah dan 2 fasa-tanah memiliki time interval beruturut-turut adalah 0,510 detik, 0,510 detik, 0,505 detik dan 0,505 detik. Relay incoming dan outgoing hasil resetting pada gangguan 3 fasa, 2 fasa, fasa-tanah dan 2 fasa-tanah memiliki time interval beruturut-turut adalah 0,331 detik, 0,350 detik, 0,479 detik dan 0,479 detik, dimana sesuai dengan Standart IEC 60255 pada gangguan maksimum saluran time interval antara relay incoming dan outgoing adalah 0,3 detik hingga 0,5 detik[8]. sehingga back-up proteksi antara relay incoming dan outgoing dapat berlangsung secara cepat dalam meniadakan gangguan yang terjadi.

Berdasarkan standart IEC 60255 time interval pada setting proteksi resetting sudah sesuai dengan standart yaitu sebesar 0,3-0,5 detik, akan tetapi pada setting proteksi existing masih belum sesuai standart IEC 60255 karena pada gangguan maksimum masih melewati time interval yaitu sebesar 0,3-0,5 detik. Sehingga perlu diatur agar grading time antara relay incoming dan outgoing berada pada interval 0,3-0,5 detik sesuai standart IEC 60255

\subsection{Waktu Ketahanan Konduktor terhadap Arus Hubung Singkat}

Gangguan hubung singkat pada saluran transmisi atau distribusi akan membuat suhu konduktor akan naik karena arus sesaat akibat hubung singkat tersebut. Berdasarkan hal tersebut maka setiap konduktor akan memiliki batas waktu tertentu untuk mampu menahan arus gangguan hubung singkat yang mengalir sebelum arus gangguan tersebut ditiadakan oleh peralatan proteksi. Berikut contoh merupakan perhitungan waktu ketahanan konduktor pada penyulang Kedonganan untuk gangguan 3 fasa di titik $0 \%$ :

Ihasa 3 fasa (0\% saluran utama) : 12322A $\mathrm{s}$ (wuas penampang konduktor) : $240 \mathrm{~mm}^{2}$

$0,287 \frac{79,25 \times \mathrm{S}}{\sqrt{7}}$ [2]

0,287 vit

$\sqrt{\mathrm{t}, 3}, \frac{2}{0,32} \frac{79,25 \times 8}{1}$

$\mathrm{t}^{0}, \frac{3}{2} \mathrm{q}, 242$ detik

Dari perhitungan diatas dengan cara yang sama dan menggunakan data nilai arus gangguan hubung singkat pada Tabel 13 didapatkan waktu ketahanan konduktor sebagai berikut.

Tabel 13. Perbandingan waktu ketahanan konduktor waktu kerja relay incoming Kedonganan

\begin{tabular}{|c|c|c|c|c|c|c|c|c|c|c|c|}
\hline \multicolumn{4}{|c|}{$\begin{array}{l}\text { Waktu Ketahanan Konduktor } \\
\text { (s) }\end{array}$} & \multicolumn{4}{|c|}{$\begin{array}{l}\text { Relay Incoming } \\
\text { Existing(s) }\end{array}$} & \multicolumn{4}{|c|}{$\begin{array}{l}\text { Relay Incoming } \\
\text { Resetting (s) }\end{array}$} \\
\hline $\begin{array}{c}3 \\
\text { fasa }\end{array}$ & $\begin{array}{c}2 \\
\text { fasa }\end{array}$ & $\begin{array}{c}1 \\
\text { fas }\end{array}$ & $\begin{array}{c}2 \\
\text { fas }\end{array}$ & $\begin{array}{c}3 \\
\text { fas } \\
\text { a }\end{array}$ & $\begin{array}{c}2 \\
\text { fasa }\end{array}$ & $\begin{array}{c}1 \\
\text { fasa- }\end{array}$ & $\begin{array}{c}2 \\
\text { fas }\end{array}$ & $\begin{array}{c}3 \\
\text { fas } \\
a\end{array}$ & $\begin{array}{c}2 \\
\text { fas }\end{array}$ & $\begin{array}{c}1 \\
\text { fas }\end{array}$ & $\begin{array}{c}2 \\
\text { fas } \\
a-a\end{array}$ \\
\hline 1,24 & 1,33 & 1,24 & 1,24 & 0,91 & 0,99 & $\frac{y}{1,12}$ & 1,2 & 0,55 & $\begin{array}{c}\mathbf{a} \\
0,57\end{array}$ & $\begin{array}{l}\mathrm{d}-\mathrm{g} \\
0,76\end{array}$ & $\begin{array}{l}a-y \\
0,76\end{array}$ \\
\hline 1,39 & 1,49 & 1,56 & 1,77 & 1,04 & 1,14 & 1,33 & 1,4 & 0,95 & 0,62 & 0,76 & 0,76 \\
\hline 1,52 & 1,63 & 1,83 & 1,98 & 1,17 & 1,30 & 1,59 & 1,7 & 0,63 & 0,67 & 0,76 & 0,79 \\
\hline 1,65 & 1,77 & 2,07 & 2,16 & 1,32 & 1,49 & 1,73 & 2,0 & 0,68 & 0,72 & 0,78 & 0,87 \\
\hline 1,77 & 1,90 & 2,28 & 2,33 & 1,48 & 1,71 & 1,93 & 2,4 & 0,72 & 0,77 & 0,83 & 0,95 \\
\hline 1,88 & 1,22 & 2,47 & 2,49 & 1,67 & 1,96 & 2,14 & 2,8 & 0,76 & 0,82 & 0,89 & 1,02 \\
\hline 1.98 & 2,13 & 2,65 & 2,64 & 1,88 & 2,26 & 2,35 & 3,2 & 0,81 & 0,87 & 0,93 & 1,09 \\
\hline 2,08 & 2,24 & 2,82 & 2,78 & 2,12 & 2,62 & 2,59 & 3,7 & 0,85 & 0,93 & 0,98 & 1,17 \\
\hline 2,18 & 2,34 & 2,98 & 2,91 & 2,41 & 3,08 & 2,84 & 4,2 & 0,90 & 0,98 & 1,03 & 1,24 \\
\hline 2,27 & 2,44 & 3,13 & 3,04 & 2,76 & 3,67 & 3,11 & 5,0 & 0,94 & 1,04 & 1,08 & 1,32 \\
\hline 2,36 & 2,54 & 3,28 & 3,17 & 3,18 & 3,37 & 3,41 & 5,9 & 0,99 & 1,09 & 1,12 & 1,39 \\
\hline
\end{tabular}

Berdasarkan Tabel 13 menunjukkan perbandingan waktu ketahanan konduktor dengan waktu kerja antara relay incoming pada kondisi setting existing, dan kondisi resetting berdasarkan IEC 60255 pada penyulang Kedonganan. Tujuan melakukan perbandingan terhadap waktu ketahanan konduktor pada kondisi existing dan resetting adalah untuk mengantisipasi rusaknya konduktor apabila terjadi gangguan sebelum gangguan tersebut ditadakan oleh peralatan proteksi. Dari Tabel 13 terlihat bahwa pada kondisi resetting relay incoming memiliki waktu kerja lebih singkat dibandingkan dengan kondisi existing

Contoh: terjadi gangguan hubung singkat 3 fasa pada jarak $70 \%(5,1233 \mathrm{~km})$ saluran, relay incoming kondisi existing dan resetting standart IEC 60255 bekerja 
berturut-berturut dengan waktu 2,128 detik dan 0,856 detik sedangkan konduktor mampu menahan gangguan hingga 2,0879 detik. Namun, dalam kondisi resetting berdasarkan standart IEC 60255, terlihat bahwa relay incoming sebagai relay backup memiliki waktu kerja lebih kecil dari waktu ketahanan konduktor. Hal ini membuktikan bahwa ketika terjadi suatu gangguan hubung singkat, maka sebelum konduktor mengalami kerusakan, relay incoming telah bekerja terlebih dahulu untuk meniadakan gangguan tersebut. Hal ini membuktikan bahwa resetting berdasarkan IEC 60255 adalah kondisi terbaik untuk diterapakan dalam sistem proteksi pada GI Nusa Dua.

\section{Kesimpulan}

Berdasarkan hasil evaluasi dan koordinasi relay proteksi arus lebih dan relay gangguan tanah memiliki nilai arus arus hubung singkat yang hampir sama dengan error ratarata untuk semua gangguan dari hasil simulasi dan hasil perhitungan yaitu sebesar $0,912 \%$. Perbedaan nilai arus setting (Iset) dan TMS pada kondisi resetting dikarenakan PT. PLN memiliki kebijakan dan pertimbangan sendiri dalam menentukan setting peralatan proteksi. Sehingga hasil resetting peralatan proteksi berdasarkan IEC 60255 memiliki nilai TMS yang berbeda dengan setting kondisi eksisting dan resetting. Waktu kerja proteksi pada kondisi eksisting pada penyulang Kedonganan dan Gardenia saat gangguan maksimum masih belum memenuhi standart grading time antar peralatan proteksi berdasarkan IEC 60255 yaitu sebesar 0,3 - 0,5 detik. Sedangkan waktu kerja masing-masing relay pada kondisi resetting telah memenuhi standart penentuan grading time berdasarkan IEC 60255 yaitu sebesar 0,3 - 0,5 detik. Waktu kerja relay incoming harus lebih cepat dari waktu ketahanan konduktor pada penyulang, sehingga kerusakan konduktor akibat arus yang mengalir pada penghantar bisa diminimalisir sehingga konduktor tidak mengalami kerusakan. Setting koordinasi proteksi hasil perhitungan (resetting) berdasarkan IEC 60255 dengan kondisi eksisting menunjukkan bahwa setting koordinasi proteksi resetting IEC 60255 dapat bekerja lebih baik dibanding dengan kondisi existing.

\section{Referensi}

[1]. APP Bali 2017, "Data Setting Relay Incoming, Data MVAsc Gardu Induk Nusa Dua-Bali".

[2]. Arismunandar, Artono. "Teknik Tegangan Tinggi, Jilid II : Saluran Transmisi", Pradnya Paramita, Jakarta. 1984.

[3]. Gardu Induk Nusa Dua "Data Trafo III Gardu Induk Nusa Dua dan Data Single line Diagram"

[4]. IEC 60255, "Overcurrent Protection for Phase and Earth Faults".

[5]. IEEE 242, Overcurrent Protection., 2001.

[6]. Jati, Catur Panuntun. 2017. "Analisis Koordinasi Setting Relay Proteksi OCR, GFR dan Recloser GIS Pudakpayung Pasca Penambahan Feeder PDP 5 Dengan Etap 12.6.0". Teknik Elektro Universitas Diponegoro. Semarang.

[7]. PT. PLN (Persero) Area Bali Selatan: 2017, "Data kabel (penghantar) Gardu Induk Nusa Dua Bali”

[8] PT. PLN (Persero) Area Pengatur Distribusi Data, Data setting relay outgoing tiap feeder

[9]. Saadat, Hadi. "Power System Analysis". McGraw Hill. 1999.

[10]. Suhadi, SMK Teknik Distribusi Tenaga Listrik Jilid I. Direktorat Pembinaan Sekolah Menengah Umum Dirjen Manajemen Pendidikan Dasar dan Menengah Departemen Pendidikan Nasional, 2008. 